\title{
PRAKTIK COST PLUS BIL WAKALAHDALAM PEMBIAYAAN SEMBAKO DI BMT UGT SIDOGIRI CABANG AROSBAYADASAR-DASAR
}

\author{
A. Taufiq Buhari \\ STAI Syaichona Moh. Cholil Bangkalan \\ taufiqbuhari@gmail.com
}

Abstract: The practice of Cost Plus bil Wakalah in the financing of basic necessities at BMT UGT Sidogiri, Arosbaya Branch includes: (I) to become a Cost Plus customer, if you have to go to BMT UGT sidogiri by disclosing what your needs are, (2) providing an explanation of the Cost Plus bil Wakalah before the contract is correct -You really understand, (3) in the procurement of goods by the customer himself because the customer is the representative for buying goods, (4) the mechanism of ownership of the goods, namely if the customer has submitted the purchase result as evidence, the BMT sells the goods to the customer, and the goods it officially becomes the property of the customer (5) guarantee for Cost Plus bill wakalah financing in the form of gold or motorized vehicle certificates, (6) the profit from Cost Plus bill Wakalah; for customers, they can buy the goods they want, for BMT; get a margin from Cost Plus, (7) if there is a delay in installments then you have to give alms to DANSOS, if there is udur syar'i it is understandable by the BMT, (8) you don't have to pay on time if the customer really doesn't have it to pay.

Keywords: BMT, DANSOS, Cost Plus bil Wakalah,

Abstrak: Praktik Cost Plus bil Wakalah dalam pembiayaan sembako di BMT UGT Sidogiri Cabang Arosbaya meliputi: (I) untuk menjadi nasabah Cost Plus bil Wakalah harus mendatangi BMT UGT sidogiri dengan mengungkapkan apa keperluannya, (2) memberikan penjelasan tentang Cost Plus bil Wakalah sebelum diakad sampai benar-benar paham, (3) dalam pengadaan barang oleh nasabah sendiri karena nasabah sebagai wakil untuk membeli barang, (4) mekanisme kepemilikan barang yaitu jika pihak nasabah telah menyerahkan nota hasil pembelian sebagai bukti, maka pihak BMT menjual barang tersebut kepada nasabah, dan barang tersebut resmi menjadi milik nasabah (5) jaminan untuk pembiayaan Cost Plus bil wakalah berupa emas atau surat-surat kendaraan bermotot, (6) keuntungan dari Cost Plus bil Wakalah; bagi nasabah bisa membeli barang yang dia inginkan, bagi BMT; mendapatkan margin dari Cost Plus, (7) jika terdapat keterlambatan angsuran maka harus memberi sedekah ke DANSOS, jika terdapat udur syar'i maka dapat dimaklumi oleh pihak BMT, (8) tidak harus membayar tepat waktu jika dari pihak nasabah benar-benar tidak punya untuk membayar.

Kata Kunci: BMT, DANSOS, Cost Plus bil Wakalah, 



\section{A. Pendahuluan}

Lembaga keuangan merupakan lembaga perantara jasa keuangan dengan masyarakat dalam rangka meningkatkan kesejahteraan ekonomi mereka. Kegiatan operasional dasar dari lembaga keuangan adalah mengumpulkan dana dari masyarakat dan menyalurkannya kembali kepada masyarakat yang membutuhkan dana tersebut. Lembaga keuangan terdiri dari dua macam yaitu Lembaga Keuangan Bank dan Lembaga Keuangan Non Bank salah satunya dalah BMT (Baitul Mal wat Tamwil).

Di daerah pedesaan belum ada lembaga keuangan non bank yang terjangkau dan mampu memberikan alternatif pelayanan (produk jasa) simpanpinjam yang cocok dengan kondisi social kultural serta kebutuhan perkonomian masyarakat menyebabkan konsep BMT (Baitul Maal wat Tamwil) dapat dihadirkan tidak hanya di daerah perkotaan tapi juga di pedesaan. BMT adalah jenis koperasi simpan pinjam yang kegiatannya berdasarkan prinsip syari’ah Islam. Baitul Maal wat Tamwil adalah gabungan dari kata "Bait Maal" dan "Bait Tamwil”. Dan BMT merupakan salah satu Lembaga keuangan syari’ ah yang sekarang sedang mengalami perkembangan yang pesat, dengan prinsip bebas dari riba, karena berpatokan pada firman Allah QS. Al-Baqarah yang artinya "Dan Allah telah menghalalkan jual beli dan mengharamkan riba” (QS. Al-Baqarah: 275).

Sudah jelas makna ayat di atas allah mengharamkan riba karena riba mengambil harta sesama manusia dengan cara yang batil, sebagaimana firman Allah SWT dalam Al-Qur'an surah an-Nisa' ayat: 29 yang artinya: "Hai orang yang beriman! Janganlah kalian saling memakan (mengambil) harta sesamamu dengan jalan yang batil, kecuali dengan jalan perniagaan yang berlaku dengan sukarela di antaramu” (QS. An-Nisa’: 29).

Konsep BMT sebagai lembaga keuangan mikro syariah, merupakan konsep pengelolaan dana (simpan-pinjam) ditingkat komunitas yang sebenarnya searah dengan konsep otonomi daerah yang bertumpu pada pengelolaan sumber daya di tingkat pemerintah (administrasi) terendah yaitu desa. Berbicara mengenai desa, tentu tidak asing lagi dengan masyarakat yang memiliki tradisi masing-masing, makhluk hidup yang unik

Volume. 8/No. 2/Juli 2020 Al-Iqtishod | 37 


\section{Praktek Cost Plus .....}

karena memiliki perbedaan antara satu individu dengan individu lainnya. Semua tindakan yang dilakukan oleh manusia atau individu pun juga berbeda-beda sesuai dengan karakter mereka masing-masing. Tindakan yang dilakukan oleh individu dalam memenuhi kebutuhan disebut perilaku konsumen. Perilaku konsumen adalah sebuah studi bagaimana individu, kelompok, dan organisasi memilih, membeli, bagaimana menggunakan barang, jasa, ide, atau pengalaman untuk memuaskan kebutuhan dan keinginan mereka. Seangakan, tindakan yang dilakukan oleh kelompok disebut organsasi. Organisasi adalah suatu kelompok orang dalam satu wadah untuk tujuan bersama. Islam menganjurkan umatnya melakukan kerjasama yang terorganisasi dengan baik. Dalam konteks itu maka kegiatan seperti murabahah (Cost Plus), musyarokah ataupun yang lainnya, itulah yang di sebut kerjasama atau organisasi dalam sebuah usaha.

Berbicara tentang produk, masyarakat tidak hanya membutuhkan suatu produk yang dikonsumsi setiap hari untuk kebutuhan melainkan ada juga produk lain yang berhubungan dengan lembaga keuangan sebagai kebutuhan. Lembaga keuangan banyak menawarkan produk-produk seperti produk tabungan dan pembiayaan. Salah satu dari produk yang ditawarkan lembaga keuangan dan paling diminati oleh masyarakat adalah produk pembiayaan. Karena masyarakat sangat membutuhkan produk tersebut untuk memenuhi berbagai macam kebutuhannya. Berbagai macam produk pembiayaan yang ada di lembaga keuangan antara lain pembiayaan dengan akad mudharabah, Cost Plus, musyarakah, ijaroh, wakalah, kafalah, dan lain sebagainya.

Di antara berbagai produk perbankan syar'iah di atas, produk jual beli Cost Plus di perbankan syari'ah pada saat ini masih mendominasi dibandingkan dengan produk bank syari’ah yang lain. Berdasarkan data di Bank Indonesia pada akhir bulan April 2019, jumlah pembiayaan perbankan syariah yang menggunakan skema Cost Plus mencapai 60\%. Ini karena dalam produk Cost Plus, prinsipkehati-hatian (prudential) bank bisa diterapkan dengan ketat dan standar sehingga tingkat risiko kerugian sangat kecil. Bahkan Bank-bank syari'ah yang baru umumnya portofolio pembiayaan nya yang paling besar menggunakan Cost Plus karena lebih aman. Sementara produk bagi hasil belum menjadi 
produk unggulan karena tingkat risiko dan kerugiannya sangat tinggi. Kecenderungan menjadikan skema Cost Plus sebagai skema pembiayaan yang utama terjadi di beberapa negara muslim seperti Bahrain Islamic Bank, Faysal Islamic Bank, Dubai Islamic Bank, Bank Islam Malaysia, Kuwait Finance House, dll, di mana kalau di rataratakan, skema Cost Plusnya mencapai prosentase 69\%. Cost Plus yang merupakan salah satu jenis jual beli yang bersifat amanat dan islam merupakan skema akad yang paling dominan digunakan dalam praktik perbankan syari’ah di Indonesia. Namun dalam prakteknya, Cost Plus telah mengalami banyak modifikasi dibandingkan konsep dasarnya yang ada dalam fiqih muamalah klasik. Modifikasi ini ada yang tidak menimbulkan persoalan dari sisi prinsipprinsip dasar hukum Islam sehingga para ulama tidak merasa keberatan, tetapi tidak sedikit model modifikasi yang menimbulkan perdebatan karena dilakukan semata-mata untuk memenuhi ketentuan formal yuridis demi pertimbangan efektivitas dan efisiensi administrasi perbankan. Pembiayaan Cost Plus memungkinkan adanya dhoman (jaminan), karena sifat dari pembiayaan Cost Plus merupakan jual beli yang pembayarannya tidak dilakukan secara tunai, maka tanggungan pembayaran tersebut merupakan hutang yang harus dibayar oleh musytari (pembeli). Bank syariah (ba'i) memberlakukan prinsip kehatihatian dengan mengenakan dhoman pada nasabah.

Modifikasi praktik Cost Plus ini juga dipraktikkan di BMT UGT Sidogiri Cabang Arosbaya salah satunya yaitu yang disebut dengan istilah Cost Plus bil Wakalah, Cost Plus adalah jual beli barang pada harga asal dengan tambahan keuntungan yang disepakati, sedangkan Wakalah dalam Fiqh Islam adalah penyerahan tugas dan tanggung jawab masing-masing pihak yang berdasarkan pada definisi Wakalah yaitu menyerahkan tugasnya atau urusannya kepada orang lain dan diserahkan tanggung jawabnya untuk bertindak bagi pihaknya. Jadi Cost Plus bil Wakalah adalah pembiayaan yang dilakukan dengan akad Cost Plus yang kemudian diikuti dengan akad Wakalah untuk melengkapinya agar sesuai dengan prinsip syariah.

Di BMT UGT Sidogiri tidak banyak nasabah yang menggunakan pembiayaan mudharabah dan musyarokah karena pihak lembaga keuangan mengalami kesulitan dalam 
Praktek Cost Plus .....

menganalisis selain itu pembiayaan mudharabah dan musyarokah ini sangat rentan mengalami risiko yang tinggi dan juga masyarakat yang belum mengerti tentang pembiayaan mudharabah dan musyarokah tersebut. Di dalam menjalankan pembiayaan Cost Plus bil Wakalah ini ternyata saling menguntungkan antara kedua belah pihak karena dinilai lebih sederhana dan lebih mudah, nasabah juga lebih nyaman untuk mencari barang yang diinginkan sesuai tujuan dari awal.

Dalam Lembaga Keuangan Syari’ah BMT UGT Sidogiri Cabang Arosbaya terdapat pembiayaan Cost Plus bil Wakalah, hal ini diterapkan karena untuk mencapai objek pihak BMT merasa kesulitan secara sumber daya manusia karena keterbatasan tenaga kerja maka BMT menerapkan sistem jual beli yang diwakilkan, BMT UGT Sidogiri juga berupaya untuk meningkatkan ekonomi masyarakat Arosbaya dan sekitarnya dengan berbagai produk. Produk pembiayaan yang tersedia di BMT UGT Sidogiri salah satunya adalah Cost Plus bil Wakalah, untuk memudahkan BMT dalam menganalisa pembiayaan maka BMT UGT Sidogiri menambahkan konsep dalam akad terebut, yaitu akad Cost Plus bil Wakalah.

\section{B. Metode Penelitian}

Penelitian ini bertujuan untuk mendiskripskan terkait praktek akad wakalah yang terdapat di lembaga keuangan BMT UGT SIDOGIRI CABANG AROSBAYADASARDASAR. Penelitian ini menggunakan pendekatan kwalitatif. Data dihimpun peneliti dengan menggunakan metode intervieu atau wawancara dan observasi. Data yang telah dihimpun peneliti kemudian dianalisis dengan pendekatan analisis deskritif.

\section{Hasil dan Pembahasan}

\section{Cost Plus Bil Wakalah}

\section{a. Pengertian Cost Plus bil Wakalah}

Cost Plus bil Wakalah adalah jual beli dengan sistem Wakalah. Dalam jual beli ini pihak Lembaga Keuangan mewakilkan pembeliannya kepada nasabah dengan demikian akad pertama adalah akad Wakalah setelah akad Wakalah berakhir yang ditandai dengan 
penyerahahn barang dari nasabah ke Lembaga Keuangan Syari' ah kemudian pihak Lembaga memberikan akad Cost Plus. Cost Plus bil Wakalah berdasarkan Fatwa Dewan Syar'iah Nasional No: 04/DSN-MUI/IV/2000, yaitu jika bank mewakilkan kepada nasabah untuk membeli barang dari pihak ketiga, akad jual beli Cost Plus harus dilakukan setelah barang secara prinsip menjadi milik Bank. Selalu terjadi akad Wakalah dulu sebelum akad Cost Plus karena akad Wakalah akan berakhir pada saat nasabah menyerahkan barang yang dibeli pada bank dan mempercepat proses pencairan dan memudahkan nasabah, sehingga setelah barang diterima oleh bank maka terjadilah akad Cost Plus.

Cost Plus pada awalnya merupakan konsep jual beli yang sama sekali tidak ada hubungannya dengan pembiayaan. Namun demikian, bentuk jual beli ini kemudian digunakan oleh perbankan syariah dengan menambah beberapa konsep lain, sehingga menjadi bentuk pembiayaan. Akan tetapi, validitas transaksi seperti ini tergantung pada beberapa syarat yang benar-benar harus diperhatikan agar transaksi tersebut diterima secara syari'ah.

\section{b. Landasan hukum yang mendasari pembiayaan Cost Plus bil Wakalah}

Al-Qur'an ialah firman Allah SWT yang di wahyukan kepada nabi Muhammad SAW dan hadits ialah berupa perbuatan, ucapan dan penyataan, yang menjadi landasan hukum mendasari Cost Plus bil Wakalah agar sesuai dengan prinsip syari' ah sehingga tidak menyimpang dari hukum islam, landasan hukumnya yaitu:

I) Al-Qur'an

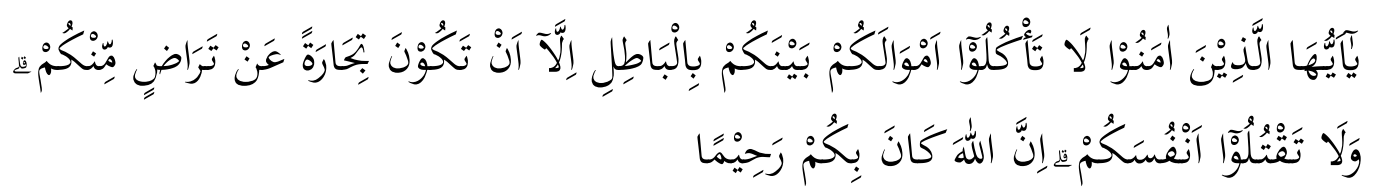

Artinya: "Hai orang-orang yang beriman, janganlah kamu saling memakan harta sesamamu dengan jalan yang batil, kecuali dengan jalan perniagaan yang berlaku dengan suka samasuka di antara kamu. Dan janganlah kamu membunuh dirimu; sesungguhnya Allah adalah Maha Penyayang kepadamu."'(QS An Nisa': 29).'

${ }^{1}$ Mushaf al-Ahzar. Al-Qur'an Dan Terjemahan. Bandung: Jabal . 2010, 83.

Volume. 8/No. 2/Juli 2020 Al-Iqtishod |4I 


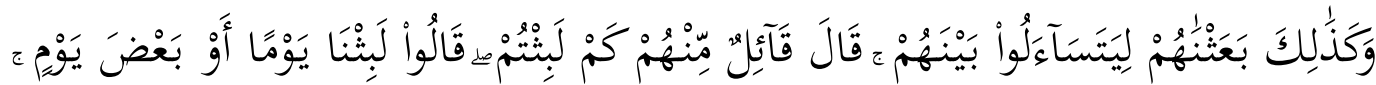



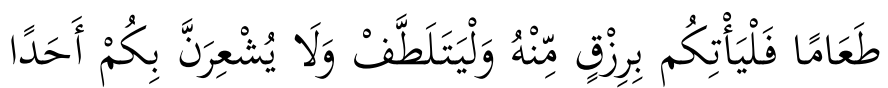

Artinya: "Dan demikianlah Kami bangunkan mereka agar mereka saling bertanya di antara mereka sendiri. Berkatalah salah seorang di antara mereka: Sudah berapa lamakah kamu berada (disini?)". Mereka menjawab: "Kita berada (disini) sehari atau setengah hari". Berkata (yang lain lagi): "Tuhan kamu lebih mengetahui berapa lamanya kamu berada (di sini). Maka suruhlah salah seorang di antara kamu untuk pergi ke kota dengan membawa uang perakmu ini, dan hendaklah dia lihat manakah makanan yang lebih baik, maka hendaklah ia membawa makanan itu untukmu, dan hendaklah ia berlaku lemah-lembut dan janganlah sekali-kali menceritakan halmu kepada seorangpun."(QS al-Kahfi: I9)2

2) Hadits

a) Hadist Nabi dari Abu Said Al-khurdi bahwa Rasulullah Saw bersabda "Sesungguhnya jual beli itu harus dilakukan suka sama suka” (HR. Al Baihaqi dan Ibnu Majah, dan dinilai Shahih oleh Ibnu Hibban).

b) Hadist Nabi riwayat Ibnu Majah, Rasulullah Saw bersabda, "ada tiga hal yang didalamnya terdapat keberkahan : jual beli secara tangguh, muqadarah (mudharabah), dan mencampur gandum dengan tepung untuk keperluan rumah, bukan untuk dijual.

c) Hadist Nabi riwayat Nisa ${ }^{\text {ee }}$, Abu dawud, Ibnu Majah, dan Ahmad bersabda, "menunda-nunda (pembayaran) yang dilakukan oleh orang mampu menghalalkan harga diri dan pemberian sanksi kepadanya”. 4) Hadist Nabi riwayat Abd Al-Raziq dari Zaid bin Aslam, Rasulullah Saw ditanya tentang Urbun (uang muka) dalam jual beli, maka beliau menghalalkannya.

\section{c. Rukun Cost Plus bil Wakalah}

Adapun rukun dari Rukun Cost Plus bil Wakalah sebagai berikut :

I) Penjual (ba'i),

2) Pembeli (musytary),

${ }^{2}$ Ibid., 295.

42| Al-Iqtishod Volume. 8/ No. 2/Juli 2020 
3) Barang yang dibeli (komoditas)

4) Harga (tsaman) yang terdiri dari harga beli margin keuntungan dan harga jual.

5) Pelaku akad, yaitu muwakil (pemberi kuasa) adalah pihak yang memberikan kuasa kepada pihak lain, dan wakil (penerima kuasa) adalah pihak yang diberi kuasa;

6) Objek akad, yaitu taukil (objek yang dikuasakan); dan

7) Shighah, yaitu Ijab dan Qabul.

\section{d. Syarat-syarat Cost Plus bil Wakalah}

I) Harus digunakan untuk barang-barang yang halal, barang najis tidak sah.

2) Diperjual-belikan dan barang bukan larangan negara.

3) Penjual memberi tahu biaya modal kepada nasabah,

4) Kontrak pertama harus sah sesuai dengan rukun yang ditetapkan,

5) Kontrak harus bebas dari riba,

6) Penjual harus menjelaskan kepada pembeli bila terjadi cacat atas barang Sesudah pembelian,

7) Penjual harus menyampaikan semua hal yang berkaitan dengan pembelian, misalnya jika pembelian dilakukan secara utang,

8) Objek akad harus jelas dan dapat diwakilkan, dan tidak bertentangan dengan syariat Islam.

\section{Pembiayaan Sembako}

\section{a. Pengertian Pembiayaan Sembako}

Secara umum bank mempunyai dua fungsi yaitu funding dan financing. Secara bahasa funding berasal dari kata fund yang artinya persediaan, menjadi kata funding (kata kerja) yang artinya pendanaan. Dalam segi istilah kata funding adalah kegiatan penempatan uang kedalam investasi atau jenis dana cadangan lain. Sedangkan financing berasal dari kata finance yang artinya keuangan dan menjadi kata financing (kata kerja) yang artinya pembiayaan. Dalam segi istilah Pembiayaan (financing) adalah pendanaan yang diberikan oleh suatu pihak kepada pihak lainuntuk mendukung investasi yang telah direncanakan, 
Praktek Cost Plus .....

baik dilakukan sendiri maupun lembaga. Pembiayaan dalam bentuk kegiatan usahanya yang meliputi pembiayaan dengan prinsip jual-beli (Cost Plus, salam, istishna), pembiayaan dengan prinsip sewa yaitu ijarah (sewa murni) dan ijarah Muntahiya bittamlik (sewa beli). pembiayaan dengan prinsip bagi hasil (musyarakah, mudharabah), akad pelengkap yaitu alkafalah, al-hawalah, al-wakalah, al-qardh dan ar-rahn. ${ }^{3}$

Pembiayaan merupakan aktivitas Lembaga Keuanagan Syari’ah dalam menyalurkan dana kepada pihak lain berdasarkan prinsip syari’ah. Penyaluran dana dalam bentuk pembiayaan didasarkan pada kepercayaan yang diberikan pemilik dana kepada pengguna dana. Pemilik dana percaya kepada penerima dana, bahwa dana dalam bentuk pembiayaan yang diberikan pasti akan terbayar. Penerima pembiayaan mendapat kepercayaan dari pemberi pembiayaan, Sehingga penerima pembiayaan berkewajiban untuk mengembalikkan pembiayaan yang telah diterimanya sesuai dengan jangka waktu yang telah diperjanjikan dalam akad pembiayaan. ${ }^{4}$

Dalam pembiayaan sembako disini merupakan pembiayaan sebuah produk dari Lembaga Keuangan Syari'ah untuk pembelian sembako baik banyak maupun sedikit dengan system Cost Plus, yang telah mengikuti syari’at Islam. Pembiayaan yang diberikan oleh pihak Lembaga Keuangan Syari'ah berbeda dengan kredit yang diberikan oleh Bank konvensional. Dalam Lembaga Keuangan Syariah, return atas pembiayaan tidak dalam bentuk bunga akan tetapi dalam bentuk lain sesuai dengan akad-akad yang disediakan di Lembaga Keuangan Syari’ah. Dalam Undang-Undang Perbankan No. I0 Tahun I998, kredit adalah penyediaan uang atau tagihan yang dapat dipersamakan dengan itu, berdasarkan persetujuan atau kesepakatan pinjam-meminjam antara Bank dan pihak lain yang mewajibkan pihak peminjam untuk melunasi utangnya setelah jangka waktu tertentu dengan pemberian bunga. ${ }^{5}$

${ }^{3}$ Azzifathur Roifah. Implementasi Pembiayaan Murabahah Bil Wakalah Sebagai Upaya Untuk Meningkatkan Ekonomi Peternak Sapi Pada Lks Asri Cabang Sendang, http://repo.iaintulungagung. ac.id/2358/

${ }^{4}$ Ismail, Perbankan syari'ah, Jakarta: Kencana Predamedia Group, 2011, 105.

${ }^{5} \mathrm{Ibid}, 106$. 
Di dalam Lembaga Keuangan Syari’ah, istilah kredit tidak dikenal, karena Lembaga Keuangan Syari’ah memiliki skema yang berbeda dengan Bank konvensional dalam menyalurkan dananya kepada pihak yang membutuhkan. Bank Syari’ah menyalurkan dananya kepada nasabah dalam bentuk pembiayaan. Sifat pembiayaan, bukan merupakan utang piutang, tetapi merupakan investasi yang di berikan Bank kepada nasabah dalam melakukan usaha.

Menurut Undang-Undang Perbankan No. I0 Tahun 1998, pembiayaan adalah penyediaan uang atau tagihan yang dipersamakan itu, berdasarkan persetujuan atau kesepakatan antar Bank dan pihak lain yang dibiayai untuk mengembalikan uang atau tagihan tersebut setelah jangka waktu tertentu dengan imbalan atau bagi hasil. Didalam perbankan syariah pembiayaan yang diberikan kepada pihak pengguna dana berdasarkan pada prinsip syari’ah. Aturan yang digunakan yaitu sesuai dengan hukum Islam.

\section{b. Tujuan Pembiayaan Sembako}

Tujuan pembiayaan Lembaga Keuangan Syari'ah dalam menyalurkan dana kepada pihak lain selain dari Lembaga Keuangan Syar' iah berdasarkan prinsip syari’ ah yaitu:

I. Meningkatkan ekonomi umat, artinya masyarakat yang tidak dapat akses secara ekonomi dengan adanya pembiayaan mereka dapat melakukan akses ekonomi. Sehingga dengan adanya produk yang telah diberikan oleh pihak Lembaga Keuangan Syari’ah diantaranya berupa pembiayaan sembako mampu meng improvisasikan nilai ekonomi umat.

2. Tersedianya dana bagi peningkatan usaha, artinya untuk pengembangan usaha Membutuhkan dana tambahan ini dapat diperoleh melalui aktifitas pembiayaan.

3. Meningkatkan produktifitas, artinya dengan adanya pembiayaan memberikan peluang bagi masyarakat agar mampu meningkatkan daya produksinya. 
Praktek Cost Plus ....

4. Membuka lapangan pekerjaan baru, artinya dengan dibukakan sektor-sektor usaha melalui penambahan dana pembiayaan, maka sektor usaha tersebut akan menyerap tenaga kerja. ${ }^{6}$

\section{c. Unsur-unsur Pembiayaan Sembako}

Unsur-unsur yang terkandung dalam pemberian suatu pemberian fasilitas pembiayaan sembako:

I. Lembaga Keuangan Syari’ah

Merupakan badan usaha yang memberikan pembiayaan kepada pihak lain yang membutuhkan dana.

2. Nasabah

Merupakan pihak yang mendapatkan pembiayaan dari Lembaga Keuangan Syari’ah, atau penggunaan dana yang disalurkan oleh Lembaga Keuangan Syari’ah.

3. Kepercayaan (Trust)

Lembaga Keuangan Syariah memberikan kepercayaan kepada pihak yang menerima pembiayaan bahwa nasabah akan memenuhi kewajiban untuk mengembalikan dana Lembaga Keuangan Syari’ah sesuai dengan jangka waktu tertentu yang diperjanjikan.

4. Akad

Akad merupakan suatu kontrak perjanjian atau kesepakatan yang dilakukan antara Lembaga Keuangan Syariah dan pihak nasabah.

5. Risiko

Setiap dana yang disalurkan/diinvestasikan oleh Lembaga Keuangan Syariah selalu mengandung risiko tidak kembalinya dana. Risiko pembiayaan merupakan kemungkinan kerugian yang akan timbul karena dana yang disalurkan tidak dapat kembali. 6. Jangka waktu

Merupakan periode waktu yang diperlukan oleh nasabah untuk membayar kembali pembiayaan yang telah diberikan oleh Lembaga Keuangan Syari’ah.

7. Balas Jasa

${ }^{6}$ Muhammad Syafi'I Antonio, Bank Syariah Bagi Bankir Dan Praktisi Keuangan. Jakarta: Tazkia Institute, 1999, 160.

46| Al-Iqtishod Volume. 8/No. 2/Juli 2020 
Sebagai balas jasa atas dana yang disalurkan oleh Lembaga Keuangan Syari’ah, maka nasabah membayar sejumlah tertentu sesuai dengan akad yang telah disepakati antara Lembaga Keuangan Syari'ah dan nasabah ${ }^{7}$.

\section{d. Fungsi dan Manfaat Pembiayaan}

Pembiayaan yang diberikan oleh Lembaga Keuangan Syari’ah berfungsi membantu masyarakat dalam memenuhi kebutuhan untuk meningkatkan usahanya. Masyarakat merupakan individu, pengusaha, lembaga, badan usaha, dan lain-lain yang membuhkan dana. ${ }^{8}$

Beberapa manfaat atas pembiayaan yang disalurkan oleh Lembaga Keuangan Syari'ah kepada nasabah antara lain, manfaat pembiayaan bagi Lembaga Keuangan Syari’ah, debitur pemerintahan, dan masyarakat luas yaitu:

I. Manfaat pembiayaan bagi Lembaga Keuangan Syariah

a. Pembiayaan yang diberikan oleh Lembaga Keuangan Syariah kepada nasabah akan mendapat balas jasa berupa bagi hasil, margin (keuntungan), dan pendapatan sewa, tergantung pada akad pembiayaan yang telah diperjanjikan antara Lembaga Keuangan Syari’ah dan nasabah.

b. Pembiayaan akan berperngaruh pada peningkatan profitabilitas Lembaga Keuangan Syariah. Hal ini dapat tercermin pada perolehan laba. Dengan adanya peningkatan laba usaha Lembaga Keuangan Syari’ah akan menyebabkan kenaikan tingkat profitabilitasnya.

c. Kegiatan pembiayaan dapat mendorong peningkatan kemampuan pegawai untuk lebih memahami secara terperinci aktifitas usaha para nasabah diberbagai sektor usaha. Pegawai Lembaga Keuangan Syari’ah semakin terlatih untuk dapat memahami berbagai sektor usaha sesuia dengan jenis usaha nasabah yang di biayai. ${ }^{9}$

\footnotetext{
${ }^{7}$ Wiroso, Jual beli Murabahah. Yogyakarta: UII Prees, 2005, 14.

${ }^{8}$ Ibid, 108.

${ }^{9}$ Binti Nur Asiyah. Manejemen Pembiyaan Bank Syariah. Yogyakarta: Kalimedia. 2015, 110.
}

Volume. 8/No. 2/Juli 2020 Al-Iqtishod | 47 
Praktek Cost Plus .....

2. Manfaat pembiayaan bagi Debitur

a. Meningkatkan usaha nasabah, pembiayaan yang diberikan oleh Lembaga Keuangan Syariah kepada nasabah memberikan manfaat untuk memperluas volume usaha, pembiayaan untuk membeli bahan baku, pengadaan mesin dan peralatan, dapat membantu nasabah untuk meningkatkan volume produksi dan penjualan.

b. Nasabah dapat memilih berbagai jenis pembiayaan berdasarkan akad yang sesuai dengan tujuan penggunaanya.

c. Jangaka waktu pembiayaan disesuaikan dengan jenis pembiayaan dan kemampuan nasabah dalam membayar kembali pembiayaannya, sehingga nasabah dapat mengestimasikan keuangan dengan tepat. ${ }^{10}$

3. Manfaat pembiayaan bagi pemerintah

a. Pembiayaan dapat digunakan sebagai alat untuk mendorong pertumbuhan sektor ril, karena uang yang tersedia di Lembaga Keuangan Syariah menjadi tersalurkan kepada pihak yang melaksanakan usaha. Pembiayaan yang diberikan kepada perusahaan untuk investasi atau modal kerja akan meningkatkan volume produksinya, sehingga meningkatkan volume produksinya akan berpengaruh pada peningkatan volume usaha dan pada akhirnya akan meningkatkan pendapatan secara nasional.

b. Secara tidak langsung pembiayaan Lembaga Keuangan Syari’ ah dapat meningkatkan pendapatan negara, yaitu pendapatan pajak antara lain, pajak pendapatan Lembaga Keuangan Syari’ah dan pajak pendapatan dari nasabah.

4. Manfaat pembiayaan bagi masyarakat

a. Mengurangi tingkat pengangguran pembiayaan yang diberikan untuk perusahaan dapat menyebabkan adanya tambahan tenaga kerja karena adanya peningkatan volume produksi, tentu akan menambah jumlah tenaga kerja.

${ }^{10}$ Ibid. 111.

48| Al-Iqtishod Volume. 8/ No. 2/Juli 2020 
b. Penyimpanan dana akan mendapat imbalan berupa bagi hasil lebih tinggi dari Lembaga Keuangan Syari’h apabila Lembaga Keuangan Syariah dapat meningkatkan keuntungan atas pembiayaan yang di salurkan. ${ }^{\text {II }}$

Pembiayaan sembako merupakan pembiayaan untuk pembelian sembako baik banyak maupun sedikit dengan system Cost Plus. Pembiayaan sembako merupakan sebuah produk yang diberikan oleh Lembaga Keuangan Syari’ah terhadap nasabah, dalam operasionalnya Lembaga Keuangan Syari’ah menggunakan beberapa skema yang bersesuaian dengan syari'ah, salah satunya pembiayaan/penyaluran dana yaitu Cost Plus. Pembiayaan Cost Plus Lembaga Keuangan Syari’ah yakni, pembiayaan berdasarkan akad jual beli antara Bank dan nasabah. Bank membeli barang yang dibutuhkan dan menjualnya kepada nasabah sebesar harga pokok ditambah dengan keuntungan margin yang disepakati. Hampir seluruh pembiayaan konsumtif Lembaga Keuangan Syari’ah menggunakan skema ini. Skema ini juga banyak dipergunakan Bank Syari’ah dalam modal kerja atau investasi yang berbentuk barang. Sekitar 90\% pembiayaan BMT UGT Sidogiri Cabang Arosbaya menggunakan skema Cost Plus bil Wakalah.

\section{Cost Plus bil Wakalah dalam pembiayaan sembako di BMT UGT Sidogiri Cabang} Arosbaya

Pembiayaan sembako merupakan pembiayaan untuk pembelian keperluan toko maupun dapur baik sedikit atau banyak dengan system Cost Plus bil Wakalah. Pembiayaan sembako merupakan sebuah produk yang diberikan oleh Lembaga Keuangan Syariah terhadap nasabah, Dalam operasionalnya Bank menggunakan dua akad dan beberapa skema yang bersesuaian dengan syari'ah, salah satunya pembiayaan/penyaluran dana dengan dua akad yaitu Cost Plus bil Wakalah. Pembiayaan Cost Plus bil Wakalah di BMT yakni, pembiayaan berdasarkan akad jual beli antara Bank dan nasabah. Bank memberikan dana kepada nasabah sekaligus menjadikannya wakil, maka disini terjadilah akad Wakalah, agar si wakil bisa membeli barang yang dia ingikan lebih cepat untuk didapatkan, setelah barang

\footnotetext{
${ }^{11}$ Ahmad Ifham Sholihin, Pedoman Umum Lembaga Keuangan Syariah. Jakarta: PT. Gramedia Pustaka, 2010, 141.
}

Volume. 8/No. 2/Juli 2020 Al-Iqtishod | 49 
Praktek Cost Plus .....

yang di inginkan si wakil/nasabah sudah didapat maka nasabah tersebut kembali ke bank dengan melakukan negosiasi dan menjualnya kepada nasabah sebesar harga pokok dan ditambah dengan keuntungan margin yang disepakati maka disitulah terjadi akad Cost Plus, karena dalam satu transaksi ini terdapat dua akad yaitu yang pertama terjadi akad Wakalah dan yang kedua akad Cost Plus sehingga pihak Lembaga Keuangan Syari’ah Menyebutnya akad Cost Plus bil Wakalah.

Aktivitas Lembaga Keuangan Syari’ah dalam menyalurkan dana kepada pihak lain berdasarkan prinsip syariah. Penyaluran dana dalam bentuk pembiayaan didasarkan pada kepercayaan yang diberikan pemilik dana kepada pengguna dana. Pemilik dana percaya kepada penerima dana, bahwa dana dalam bentuk pembiayaan yang diberikan pasti akan terbayar. Penerima pembiayaan mendapat kepercayaan dari pemberi pembiayaan, Sehingga penerima pembiayaan berkewajiban untuk mengembalikkan pembiayaan yang telah diterimanya sesuai dengan jangka waktu yang telah diperjanjikan dalam akad pembiayaan. ${ }^{12}$

Dalam pelaksanaan akad ini, pihak BMT UGT Sidogiri Cabang Arosbaya memberikan kuasa kepada nasabahnya untuk membeli barang yang diperlukan untuk usaha nasabah yaitu sembako, akan tetapi dalam transaksinya atas nama BMT, nasabah hanya sebagai wakil pebeliannya. Selanjutnya, BMT UGT Sidogiri Cabang Arosbaya menjual barang (sembako) kepada nasabah dimana harga jual barang tersebut adalah harga pokok barang ditambah margin keuntungan yang total seluruhnya akan dibayar oleh nasabah dalam jangka waktu tertentu, sesuai dengan kesepakatan antara bank dan nasabah.

Dalam proses tersebut akadnya adalah akad Cost Plus bil Wakalah, dimana pihak bank mewakilkan pembelian barang kepada nasabah sepenuhnya dan pihak bank hanya memberikan dana untuk pembelian barang yang dinginkan oleh nasabah berupa sembako. Dalam hal ini akad awal yang dipergunakan oleh bank untuk pencapaian dana adalah akad

${ }^{12}$ Ismail, Perbankan Syariah edisi pertama. Jakarta: Kencana, 2011, 108. 
Cost Plus yang kemudian disertai dengan akad Wakalah, akan tetapi saat kontrak Cost Plus berlangsung objek barang akan di Cost Plus-kan belum dimiliki oleh bank. ${ }^{13}$

Dalam pembiayaan sembako disini merupakan pembiayaan sebuah produk dari BMT UGT Sidogiri Cabang Arosbaya untuk pembelian sembako baik banyak maupun sedikit dengan system Cost Plus bil Wakalah, yang telah mengikuti syariat Islam. Pembiayaan yang diberikan oleh pihak BMT berbeda dengan kredit yang diberikan oleh Bank konvensional. Dalam Lembaga Keuangan Syari’ah, return atas pembiayaan tidak dalam bentuk bunga akan tetapi dalam bentuk lain sesuai dengan akad-akad yang disediakan di dalam Lembaga Keuangan Syari’ah. Dalam Undang-Undang Perbankan No.I0 Tahun 1998, kredit adalah penyediaan uang atau tagihan yang dapat dipersamakan dengan itu, Berdasarkan persetujuan atau kesepakatan pinjam-meminjam antara Bank dan pihak lain yang mewajibkan pihak peminjam untuk melunasi utangnya setelah jangka waktu tertentu dengan pemberian bunga. ${ }^{14}$

Adapun Skema system Cost Plus bil Wakalah BMT UGT Sidogiri Cabang Arosbaya sebagai berikut :

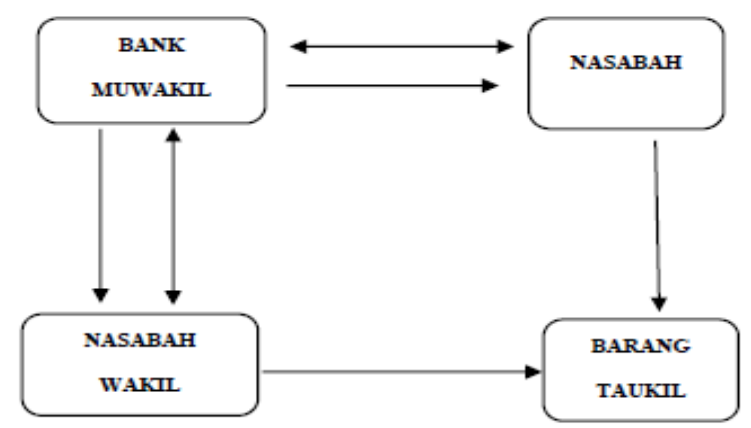

Berdasakan praktik akad Cost Plus bil Wakalah di atas, agar penelitian terarah, maka kerangka konseptual dari penelitian ini adalah sebagai berikut: bahwa Bank dan Nasabah melakukan akad Cost Plus bil Wakalah, kemudian bank

${ }^{13}$ Ahmad Malidizen \& Joni Tamkin Borhan. Aplikasi Pembiayaan Modal Kerja Cost Plus Bi Al-Wakalah. Jurnal, Surabaya, Departemen Of Syariah And Economic, Academy Of Islamic Studies, University Of Malaya, 2016, 11.

${ }^{14}$ Ibid, 134 .

Volume. 8/No. 2/Juli 2020 Al-Iqtishod |5I 
Praktek Cost Plus .....

menyerahkan dana kepada nasabah atau wakil, dan si wakil membeli barang ke taukil atau supplier, kemudian supplier mengirimkan barang ke nasabah/wakil, selanjutnya nasabah membayar ke bank secara cicil diangsur sesuai dengan kesepakatan sebelumnya.

\section{Simpulan}

Praktik Cost Plus bil Wakalah dalam pembiayaan sembako di BMT UGT Sidogiri Cabang Arosbaya meliputi: (I) untuk menjadi nasabah Cost Plus bil Wakalah harus mendatangi BMT UGT sidogiri dengan mengungkapkan apa keperluannya, (2) memberikan penjelasan tentang Cost Plus bil Wakalah sebelum diakad sampai benar-benar paham, (3) dalam pengadaan barang oleh nasabah sendiri karena nasabah sebagai wakil untuk membeli barang, (4) mekanisme kepemilikan barang yaitu jika pihak nasabah telah menyerahkan nota hasil pembelian sebagai bukti, maka pihak BMT menjual barang tersebut kepada nasabah, dan barang tersebut resmi menjadi milik nasabah (5) jaminan untuk pembiayaan Cost Plus bil wakalah berupa emas atau surat-surat kendaraan bermotot, (6) keuntungan dari Cost Plus bil Wakalah; bagi nasabah bisa membeli barang yang dia inginkan, bagi BMT; mendapatkan margin dari Cost Plus, (7) jika terdapat keterlambatan angsuran maka harus memberi sedekah ke DANSOS, jika terdapat udur syar'i maka dapat dimaklumi oleh pihak BMT, (8) tidak harus membayar tepat waktu jika dari pihak nasabah benar-benar tidak punya untuk membayar.

\section{E. Daftar Pustaka}

al-Ahzar, Mushaf. Al-Qur'an Dan Terjemahan. Bandung: Jabal . 2010.

Al-Hikmah. Al-Qur'an Dan Terjemahannya. Bandung: Ponogoro. 2013.

Antonio, Muhammad Syafi'I. Bank Syariah Bagi Bankir Dan Praktisi Keuangan. Jakarta: Tazkia Institute, I999.

Asiyah, Binti Nur. Manejemen Pembiyaan Bank Syariah. Yogyakarta: Kalimedia. 2015.

Fathullah. Analisis Penerapan Peraturan Bank Indonesia No. 7/46/PBI/20I5 Terhadap Praktek Wakalah Dalam Pembiayaan Di BMT UGT Sidogiri Capem Konang Bangkalan, tt.

Ismail, Perbankan syari’ah, Jakarta: Kencana Predamedia Group, $201 \mathrm{I}$.

Ismail, Perbankan Syariah edisi pertama. Jakarta: Kencana, 201 I.

52| Al-Iqtishod Volume. 8/No. 2/Juli 2020 
A. Taufiq Buhari

Kurniawan, Ari. Muamalah Perdagangan BisnisSyari’ah. Justia Jurnal Hukum, volume I0, issue 02, April 2017.

Malidizen, Ahmad \& Joni Tamkin Borhan. Aplikasi Pembiayaan Modal Kerja Cost Plus Bi Al-Wakalah. Jurnal, Surabaya, Departemen Of Syariah And Economic, Academy Of Islamic Studies, University Of Malaya, 2016.

Muhammad. Etika Bisnis Islami. Yogyakarta: Akademia Managemen Perusahaan YKPN. 2004.

Saparie, Gunoto. Dominasi Murabahah bil Wakalah di Bank Syarïah.

Sholihin, Ahmad Ifham. Pedoman Umum Lembaga Keuangan Syariah. Jakarta: PT. Gramedia Pustaka, 2010.

Wiroso, Jual beli Murabahah. Yogyakarta: UII Prees, 2005.

Volume. 8/No. 2/Juli 2020 Al-Iqtishod | 53 